RESEARCH ARTICLE

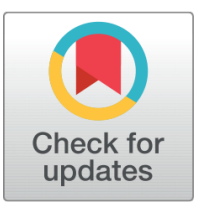

OPEN ACCESS

Received: $19-04-2020$

Accepted: $24-07-2020$

Published: $31-07-2020$

Editor: Dr. Natarajan Gajendran

Citation: Kumar R, Kumar G, Kumar M, Guleria RP (2020) Spectral and seasonal variations of aerosol radiative forcing with special reference to Kanpur, Indo-Gangetic Basin. Indian Journal of Science and Technology 13(27): 2774-2785. https ://doi.org/10.17485/IJST/v13i27.308

*Corresponding author. Gulshan Kumar

Department of Physics, Govt. College Sarkaghat, District Mandi, 175024, Himachal Pradesh, India. Tel.: +919418195031

goldy_physics@rediffmail.com

Funding: None

Competing Interests: None

Copyright: @ 2020 Kumar, Kumar, Kumar, Guleria. This is an open access article distributed under the terms of the Creative Commons Attribution License, which permits unrestricted use, distribution, and reproduction in any medium, provided the original author and source are credited.

Published By Indian Society for Education and Environment (iSee)

\section{Spectral and seasonal variations of aerosol radiative forcing with special reference to Kanpur, Indo-Gangetic Basin}

\author{
Raj Kumar,2, Gulshan Kumar ${ }^{3 *}$, Mukesh Kumar ${ }^{4}$, Raj Paul Guleria ${ }^{5}$ \\ 1 Department of Physics, Career Point University Kota, Kota, 324005, Rajasthan, India \\ 2 Department of Physics, Govt. College Ghumarwin, District Bilaspur, 174021, Himachal \\ Pradesh, India \\ 3 Department of Physics, Govt. College Sarkaghat, District Mandi, 175024, Himachal Pradesh, \\ India. Tel.: +919418195031 \\ 4 Department of Physics, Lovely Professional University, Phagwara, 144411, Punjab, India \\ 5 Department of Higher Education, Govt. Of Himachal Pradesh, Himachal Pradesh, 171001, \\ India
}

\section{Abstract}

Objective: To find the influence of aerosols on the sun rays arriving at the surface and to measure aerosol radiative forcing over Kanpur, Indo-gangetic basin. The study was performed during period 2001-2015. Methodology: The present work is credited to the availability of data through the network relying on the ground based optical observations obtained with the help of ground based instrument called Cimel sun photometer using AERONET (Aerosol Robotic Network) radiative transfer model with particular focus on Indo-Gangetic plain over Kanpur. The aerosol radiative forcing at the surface, atmosphere and top of atmosphere has been computed with the help of radiative transfer approach depending on AERONET aerosol retrievals. Findings: Our study investigated the seasonal and spectral variations of ARF along with aerosol radiative forcing with special reference to Kanpur region (IGP) by using AERONET data. The monthly average $( \pm \sigma)$ ARF during the entire observational period (2001-2015), at three levels i.e., surface (ARFSFC), atmosphere (ARFATM) and the atmospheric top (ARFTOA) are recorded as $89.6 \pm 18.6 \mathrm{Wm}-2,+64.4 \pm 16.5 \mathrm{Wm}-2$ and $-25.2 \pm 6.8 \mathrm{Wm}-2$ respectively. From the ARF measurements, it is found that there is a large reduction in surface arriving solar rays due to presence of absorbing and scattering types of aerosols. Novelty: Since this study provides an overview of the present state of prevailing aerosols and their climatic effects. So, findings may be used to create an aerosol climate map for the region under study.

Keywords: Aerosol robotic network; aerosol radiative forcing; global atmospheric model; sun photometer 


\section{Introduction}

Aerosols engender disturbances in earth's energy system thereby changing earth's energy balance changes completely, it is referred to as radiative forcing. The imposed perturbations are brought by atmospheric species e.g., $\mathrm{CO}_{2}$, aerosols etc. Generally, atmospheric models are used to find the atmospheric results affected by a single factor. However, during investigation of the atmospheric result affected by a single factor, it is not found appropriate to know cause and effect and hence such models are avoided to replicate the result related to each area of interest. Earth's atmosphere is affected mostly by energy of the sun. This energy falls at the atmospheric top, crosses through atmosphere and arrives at the surface of earth. A major quantum of energy is returned back into the atmosphere, named scattering whereas a part is absorbed by aerosols, named absorption ${ }^{(1-4)}$. These phenomena have explicit impact on Earth's energy ${ }^{(2,4,5)}$. Atmospheric radiation budget comprises solar rays released from the sun as well as thermal rays emitted from the Earth's surface. As a result of this, smaller amount of sunlight arrives at the surface of earth and thus gives rise to cooling effect at regional level. Whereas aerosol absorption has reverse impact and leads to warming effect on the environment. Thus, aerosols affect the atmosphere in several ways. There is a strong interaction between aerosols and solar radiations and hence aerosols have a significant repercussion on environmental change. The consequence of this interaction is that the earth's radiative balance is strongly affected. It is noted that the transport of atmospheric dust has a great repercussion and the amount of solar radiations arriving at the surface are greatly reduced. The transported aerosols mixed with carbonaceous aerosols emitted from industries and urban sites develop a tropospheric temperature abnormality.

The deposition of black carbon on the snow-covered area increases its absorption and thus the albedo power of snow surface decreases. As a result, its efficiency for absorption of solar radiation increases, thereby warming the surface and leads to glacier retreat. Its example is retreat of the Tibetan Plateau ${ }^{(6,7)}$. This process gives a momentum to melting of Tibetan glaciers ${ }^{(8)}$. These types of effects were also observed $2 \mathrm{~km}$ around the northern Indian Ocean and approximately $4 \mathrm{~km}$ in mid parts of India. Due to this mechanism, the temperature gradient of $4 \mathrm{~K} / \mathrm{km}$ is created which is enough to change the water cyclic process and thus the monsoon in the Indian sub-continent ${ }^{(4,9,10)}$. High magnitude of combining black carbon aerosols on bright clouds causes the increase in the absorption efficiency. Due this fact the shrinking of glaciers has been reported in Indian Himalayan region ${ }^{(11,12)}$. A small proportion of the soot aerosols in the optical depth of aerosol can accelerate the melting of glaciers. This may cause the alarming effect on the earth's environment especially related to the existence of Glaciers ${ }^{(13-15)}$. The black carbon has a main contribution in the attenuation of the reflectance of snow in the aggregation regions of glaciers in the Baspa Valley of Himachal Pradesh ${ }^{(16)}$.

The particle size distribution and chemistry are very different. The transported aerosol is mixed with carbon aerosols (emitted by industry and urban areas) to increase the efficiency of the absorption of solar radiation which can lead to anomalies in the tropospheric temperature. In addition, the Indian subcontinent has a very complex meteorology with enormous potential currents, different sea surface temperatures, strong medium-sized circulation and vast topography. These factors make remote sensing and modeling difficult in the Indian region. In addition, the India region is one of the regions in the world where the assumptions and algorithms of aerosols can be fully highlighted. The average description of the aerosol is mainly divided into two types of layers; one is the surface layer (SL), which extends to $1.5 \mathrm{~km}$ and the second is the high aerosol layer (EAL) which extends between 1.5 and $5.5 \mathrm{~km}$. The improvement in the net column aerosol load compared to Kanpur is related to a relatively larger increase in contributions due to the EAL load compared to $\mathrm{SL}^{(17)}$.

The measurements of aerosol optical properties and radiative forcing have been done by using remote sensing devices such as ground - based sensor: CIMEL sun photometer and satellite- based sensors: Moderate Resolution Imaging SpectroradiometerMODIS \& Cloud-Aerosol Lidar with Orthogonal Polarization- CALIOP over Indian region with particular focus on IndoGangetic Plain. The study from this part of India is important of Aerosol from this part of India is important because the accumulation of the aerosol particularly mixing state of aerosols has impact on atmospheric thermodynamics ${ }^{(15)}$. The AERONET is a broad remote sensing aerosol network based on ground-based observations obtained from the device called CIMEL sun photometer. Everyday observations of the optical depth of the aerosol recorded by MODIS Terra satellite in the region of the Indo- Gangetic Basin are also in good agreement with the measurements by AERONET ${ }^{(18)}$. Regionally, there are various aerosols networks. India started the systematic study of aerosols in the year 1988 under Indian Middle Atmospheric characterization Programme (IMAP) and another programme named Aerosol Climatology and Effects was commenced in 1991. ARFI (Aerosol Radiative Forcing over India) network programme is currently doing excellent work in this area. This is one of the biggest programmes implemented in India having greater than 40 ARFI network stations. ${ }^{(19)}$.

Earlier, the radiative forcing estimates were provided for three aerosol effects ${ }^{(20)}$ : (i) aerosol having direct effect. It is the interaction of the aerosols with radiations. (ii) cloud albedo effect- radiative forcing of the aerosols. It is the interaction of the aerosols with radiations. (iii)surface albedo- black carbon effect on ice and snow. Nowadays (terminology change), the radiative forcing because of interaction between aerosol and solar rays causes both scattering as well as absorption. The estimate of radiative forcing because of the interaction between radiation and aerosol has so far been more uncertain than the present 
estimate of radiative forcing. The significant advancement in the aerosol observation system with little uncertainty is an instance of recent development. This is due to availability of data via the network based on the ground-based optical observations -AERONET, satellite-based instruments like MODIS and MISR, and others which bestowed to constrain present radiative forcing with the help aerosol observations. The properties obtained from sun-photometer in the course of pre-monsoon period are used to reckon radiative forcing at the upper atmosphere and at the facet of the Indio- Gangetic region ${ }^{(21)}$.

Aerosol radiation interaction greatly impacts the adscription of $\mathrm{PM}_{2.5}$ air pollution changeability to emission variations and meteorology ${ }^{(22)}$. The diffuse part of global radiation related with the aerosols direct effect, which is precluding clouds effect, increases with the increase of aerosol loading ${ }^{(23)}$. During past decades, rapid boost of air pollution was noticed in China, giving rise to tremendously high value of aerosol radiative forcing, about ten times large in comparison to the global means ${ }^{(24)}$. Whether aerosols are functioning as CCN or IN or commonly modifying the stability of the atmosphere due to the absorption of solar radiation, yet there is large uncertainty related to their impacts on the lifetime of cloud ${ }^{(25)}$. This study provides an overview of the present state of prevailing aerosols and their climatic effects. The findings may be used to create an aerosol climate map for the Kanpur region and encourage the researcher to carry on the monitoring of aerosol from various parts of the world. This work aimed to find the influence of aerosols on the sun rays arriving on the surface and aerosol radiative forcing' during 2001 to 2015 over Kanpur.

\section{Study Area}

The aerosol radiative forcing at the surface, atmosphere and top of atmosphere has been computed with the help of radiation model based on AERONET (Aerosol Robotic Network) aerosol retrievals. The AERONET is a comprehensive remote sensing aerosol network using application of ground based observations obtained from the device called CIMEL sun photometer. Under this world-wide network, the data has been obtained from CIMEL sun photometer situated at Kanpur $\left(26.51^{\circ} \mathrm{N}, 80.23^{\circ} \mathrm{E} ; 123 \mathrm{~m}\right.$ amsl; period:2001-2015) under AERONET programme (Source: http://aeronet.gsfc.nasa.gov).

AERONET site Kanpur is located on the basin of Indo-Gangetic plain which is considered as an urban industrialized region ${ }^{(26)}$. Thus this region is the main source of anthropogenic aerosols which introduce a significant impact for the spectral and seasonal variations of aerosol forcing. ARFI network programme is doing tremendous job in the field of aerosol study

\section{Methodology}

AERONET radiative transfer approach has been used to find aerosol radiative forcing. Radiative transfer means the process in which energy transmission takes place as electromagnetic waves. The transmission of sun rays in the atmosphere is influenced by absorption, emission as well as scattering mechanisms. In present study, the evaluations of clear-sky direct aerosol radiative forcing (ARF) has been executed by applying transfer module which is desegregated into operational AERONET inversion code. This module uses several characteristics of columnar aerosols recovered by AERONET. The important characteristics are complex refractive index, aerosol optical depth, phase function, aerosol size distribution, single scattering albedo and a small amount of spherical particles.

It is a four stream plane in the form of delta in parallel with broadband radiative transfer code. In the region of shortwave having range from $0.2-4.0 \mu \mathrm{m}$ with over 200 size sub-intervals, the ARF clear-sky calculations depends on Discrete Ordinate Radiative Transfer (DISORT) module ${ }^{(27)}$. The, extinction coefficient, phase function and single scattering albedo are computed with the help of obtained size distribution corresponding to every one size sub-intervals after a same process as in the case of AERONET collection scheme. The spectral complex refractive index $(\mu(\lambda)$ and $\mathrm{k}(\lambda))$ are extrapolated and interpolated linearly with respect to the values $\mu(\lambda)$ and $\mathrm{k}(\lambda)$ obtained at the AERONET wavelengths. The same process is used to find the values of surface reflection. Radiative fluxes are calculated by taking into account a plane-parallel atmosphere in an angular range of solar zenith angles i.e., $50^{\circ}-80^{\circ}$. It is considered that the solar geometry conditions in this range are most suitable for retrieving the properties of aerosol. The correlated k-distribution method is applied to treat the absorption of non-gray gaseous caused by $\mathrm{H}_{2} \mathrm{O}, \mathrm{CO}_{2}, \mathrm{O}_{3}, \mathrm{~N}_{2} \mathrm{O}$, and $\mathrm{CH}_{4}{ }^{(28-30)}$.

Global Atmospheric Model (GAME) code is utilized to obtain the desegregation of absorption as well as scattering of atmospheric aerosol, molecular scattering by molecules, absorption by gas and impacts of surface reflection. The correlated kdistribution permits to consider the interactions between absorption by the gas and multiple scattering with possible calculated time. The correlated k-distribution coefficients are assessed from reference calculations with the help of line by line code ${ }^{(31)}$. The model considers a spectral absorption of ozone within the wavelength ranging from $0.2-0.35 \mu \mathrm{m}$ (ultra violet spectrum) and 0.5-0.7 $\mu \mathrm{m}$ (visible spectrum) whereas the water vapour gives rise to spectral absorption of ozone with range of wavelength from $0.8-3 \mu \mathrm{m}$ (infrared spectrum). The code incorporates the amount of total ozone obtained from total ozone mapping Spectrometer (TOMS) measurements. AERONET GAME code applies a constant spectral resolution of value $100 \mathrm{~cm}^{-1}$ within 
range 2500 to $17700 \mathrm{~cm}^{-1}$ (4 to $0.6 \mu \mathrm{m}$ ) and also $400 \mathrm{~cm}^{-1}$ within range $17700 \mathrm{~cm}^{-1}$ to $50000 \mathrm{~cm}^{-1}(0.6$ to $0.2 \mu \mathrm{m})$. The more detailed approach is also given in various literatures ${ }^{(28,32,33)}$.

The radiative properties of aerosol can also be obtained from OPAC (Optical Properties of Aerosol and Clouds) model ${ }^{(34)}$. The results taken from this model contain shortwave direct, diffuse, and total irradiance of shortwave at the atmospheric top, earth's surface and also in every atmospheric layer. The influence of aerosols on surface radiative flux is called as surface (SFC) radiative forcing whereas on the top of the atmosphere radiative flux, it is called radiative force at the top of atmosphere (TOA). The net fluxes difference with and without aerosol at the TOA and at the SFC results in aerosol radiation forcing at TOA and SFC respectively ${ }^{(35)}$.

The equation for Aerosol radiative forcing at TOA and SFC is given by,

$$
A R F_{T O A, S F C}=\frac{\int_{0}^{24}\left[\text { Flux }(\text { net })_{\text {with aerosol }} \text { TOA,SFC }- \text { Flux }(\text { net })_{\text {without aerosol TOA, SFC }}\right] d h}{\int_{0}^{24} d h}
$$

The expression for the change in aerosol radiative forcing $(\Delta \mathrm{F})$ is,

$$
\Delta \mathrm{F}_{\mathrm{TOA}, S F C}=\operatorname{flux}\left(\mathrm{F}^{\downarrow}-\mathrm{F}^{\uparrow}\right)_{\text {with aerosol TOA,SFC }}-\text { flux }\left(\mathrm{F}^{\downarrow}-\mathrm{F}^{\uparrow}\right) \text { without aerosol TOA,SFC }
$$

where $\mathrm{F}^{\downarrow}$ represents downward flux whereas $\mathrm{F}^{\uparrow}$ upward flux.

The atmospheric forcing is given by,

$$
A R F_{A T M}=A R F_{T O A}-A R F_{S F C}
$$

The $\Delta \mathrm{F}_{A T M}$ is the energy retained through the atmosphere by the aerosol presence and is used to obtain the influence of aerosols on climate taking into consideration hydrostatic equilibrium and the First Law of Thermodynamics ${ }^{(36)}$ :

$$
\frac{\partial T}{\partial t}=\frac{g_{e}}{C_{p}} \frac{\Delta A R F_{A T M}}{\Delta P}
$$

where $\partial \mathrm{T} / \partial \mathrm{t}$ is the rate at which atmosphere is heated in $\mathrm{K}^{\circ}$ per day, $\mathrm{g}_{e}$ is the acceleration value due to gravity of earth, $\mathrm{C}_{p}$ is the specific heat capacity at a constant value of pressure due to air $=1006 \mathrm{~J} \mathrm{~kg}^{-1} \mathrm{~K}^{-1}$ and $\Delta \mathrm{ARF}_{A T M}$ represents the atmospheric forcing. $\Delta \mathrm{P}$ represents the atmospheric pressure difference $(300 \mathrm{hPa})$ which corresponds to difference in pressure between surface and $3 \mathrm{~km}$ height. A flow chart illustrating the entire AERONET scheme, incorporating inversion process with simulation of solar fluxes is shown in Figure 1.

Although ARF estimate gives the net radiative effect of aerosols present in atmosphere, but for a consistent distinction the aerosol radiative forcing efficiency is more suitable and is given by

$$
\Delta F_{S F C, T O A}^{E f f}=\frac{\Delta F_{S F C, T O A}}{A O D_{500 \mathrm{~nm}}}
$$




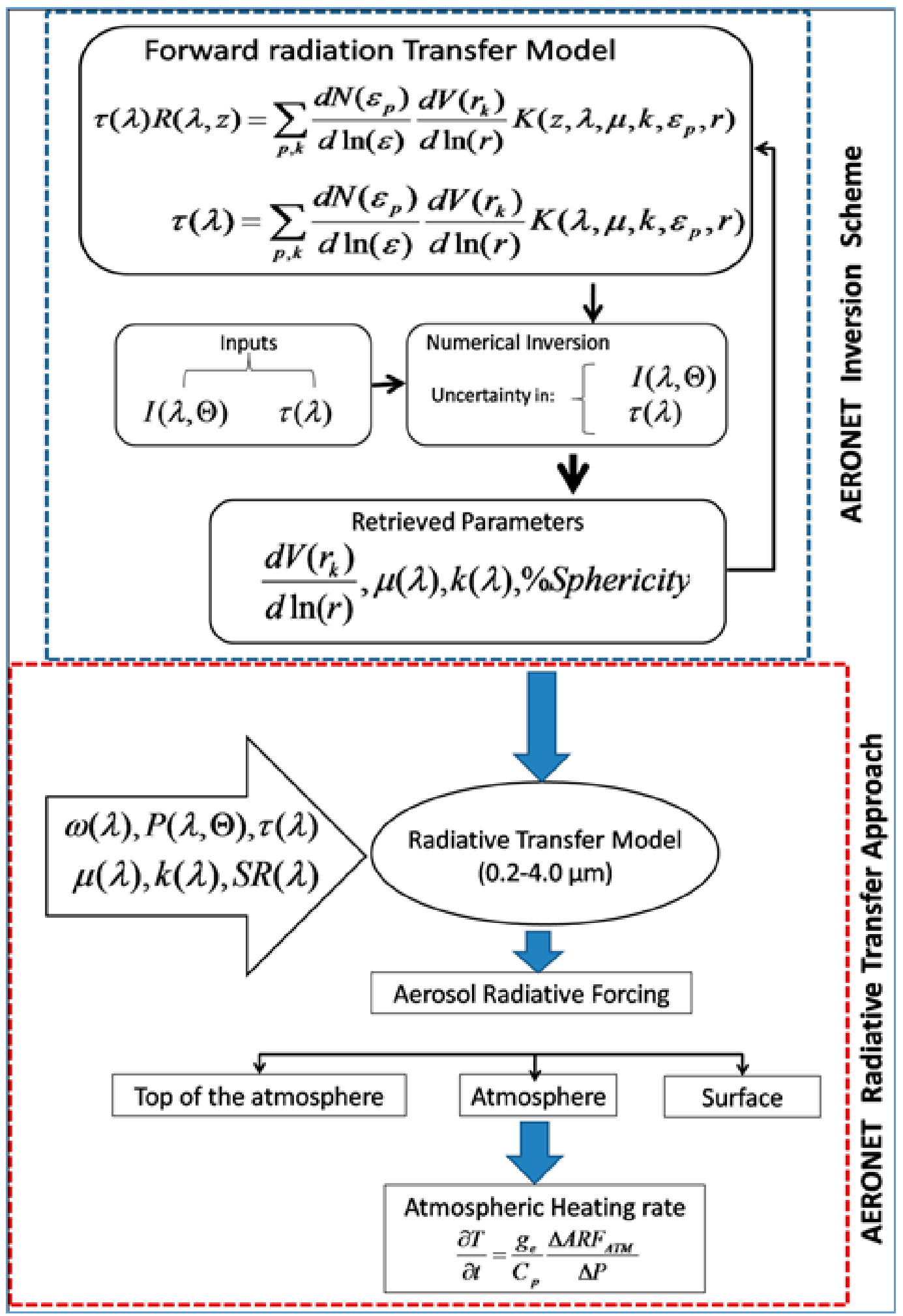

Fig 1. Flow chart describing the methodology adopted toestimate shortwave aerosol radiative forcing, using measured aerosol characteristics (aerosol optical depths, single scattering albedo, asymmetry factor, Phase function, size parameters, complex refractive index and others. 


\section{Result and Discussion}

\subsection{Seasonal variations in aerosol radiative forcing}

The monthly average $( \pm \sigma)$ ARF during the entire observational period (2001-2015), at three levels i.e., surface $\left(\mathrm{ARF}_{S F C}\right)$, atmosphere $\left(\mathrm{ARF}_{A T M}\right)$ and the atmospheric top $\left(\mathrm{ARF}_{T O A}\right)$ are recorded as $-89.6 \pm 18.6 \mathrm{Wm}^{-2},+64.4 \pm 16.5 \mathrm{Wm}^{-2}$ and $-25.2 \pm$ $6.8 \mathrm{Wm}^{-2}$ respectively. The values of ARF changes -7 to $-43 \mathrm{Wm}^{-2},-41$ to $138 \mathrm{Wm}^{-2}$ and +24 to $+106 \mathrm{Wm}^{-2}$ at the surface (SFC), top of the atmosphere (TOA)and atmosphere (ATM) respectively. Figure 2 shows the estimated values of seasonal variation in $\mathrm{ARF}$ at the TOA, SFC, and ATM.

Pre-monsoon

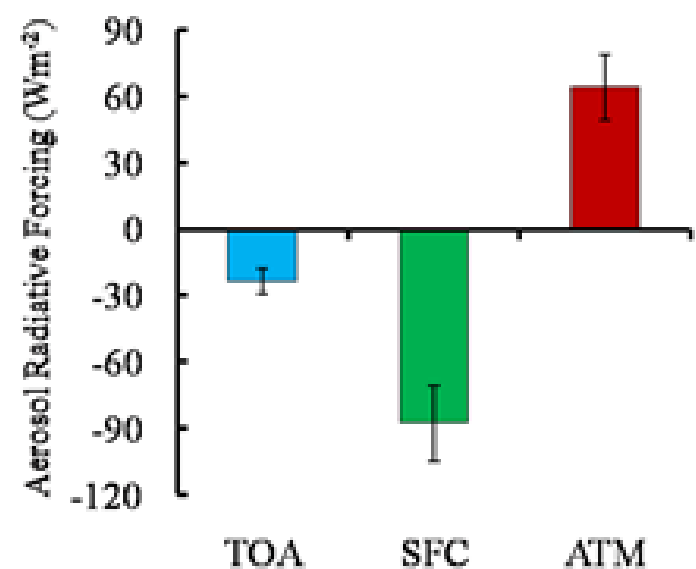

TOA SFC ATM

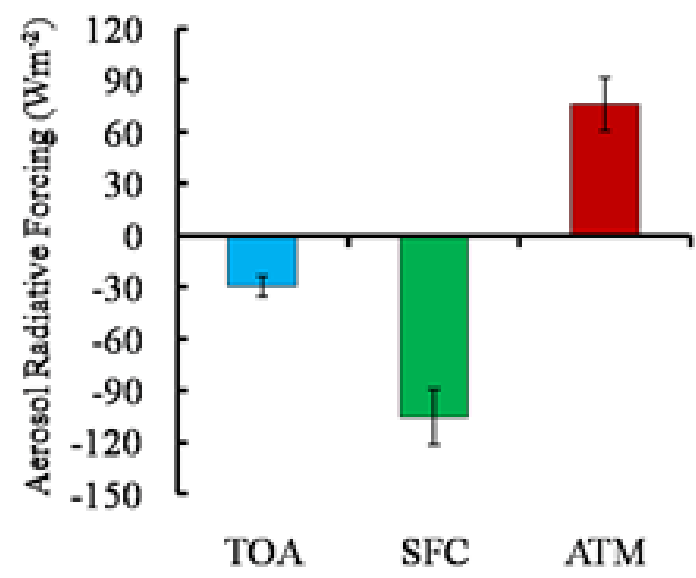

Monsoon

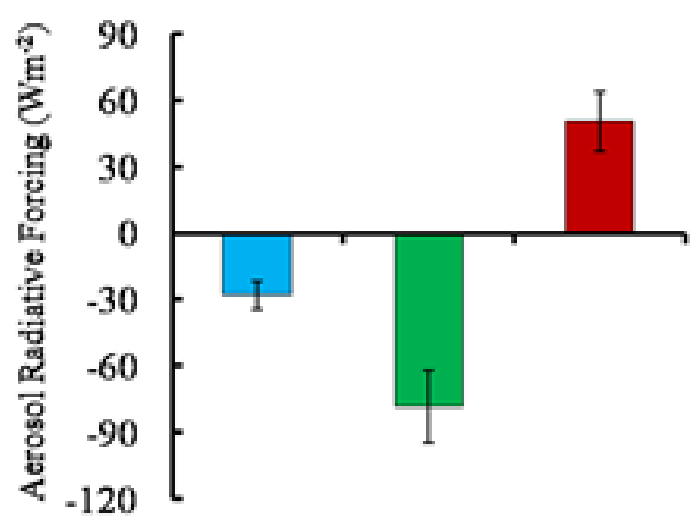

TOA SFC ATM

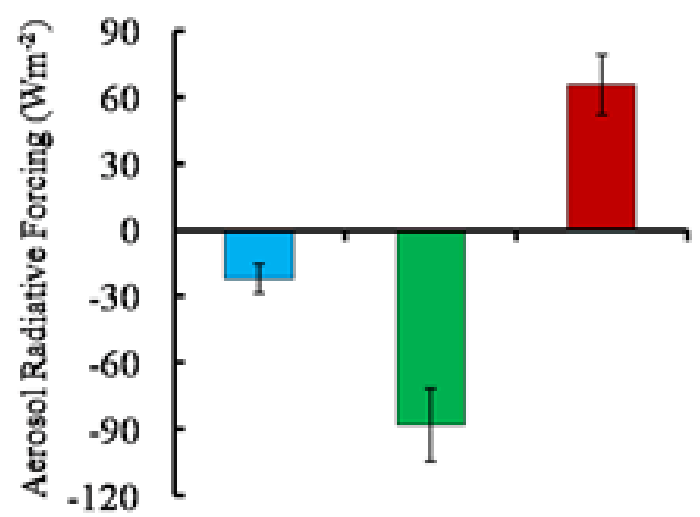

TOA SFC ATM

Fig 2. Seasonal variations of ARF for 15-years dataset(2001-2015) over Kanpur

The lowest value of ARF is found during monsoon period. The highest value of atmospheric forcing is found during the postmonsoon period which is due to the aerosols absorptive properties (SSA at $675 \mathrm{~nm}=0.91$ ). Monsoon is the period with the least absorptive aerosols while maximum value of SSA is observed. The aerosol forcing during the pre-monsoon is attributed to desert dust while in post-monsoon, it is due to polluted dust. We do not estimate large change in surface ARF in comparison with AOD since SSA is maximum (minimum)while AOD is maximum (minimum). Our study shows that large solar rays are attenuated for a given value of AOD. The AOD at $340 \mathrm{~nm}$ and $500 \mathrm{~nm}$ consistently increased with effect from pre-monsoon (March-May) to post-monsoon (October-November) with values $41 \%$ and $33 \%$ respectively because mostly the weather remains raining and cloudy in this period and effects the measurements ${ }^{(37)}$. 


\subsection{Spectral variation in monthly average aerosol radiative forcing}

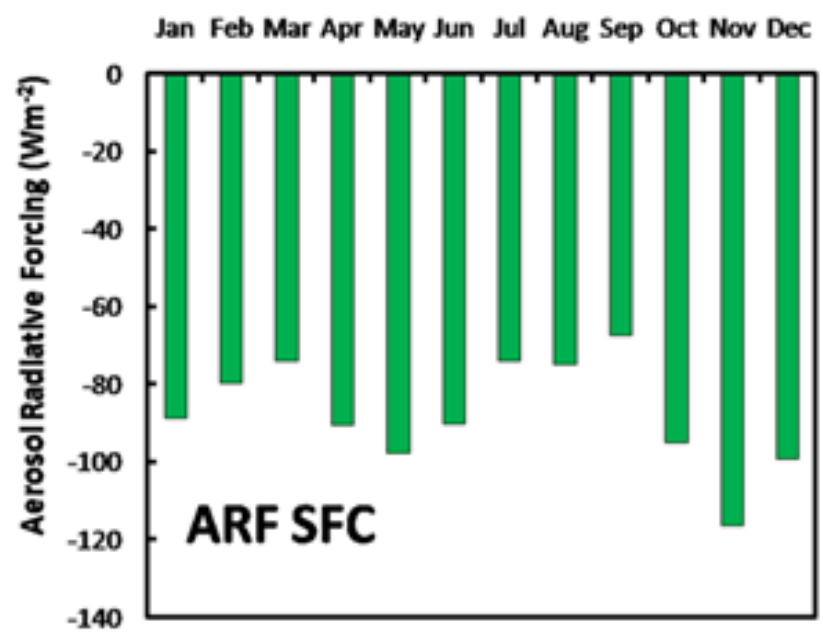

Jan Feb Mar Apr May Jun Jul Aug Sep Oct Nov Dec
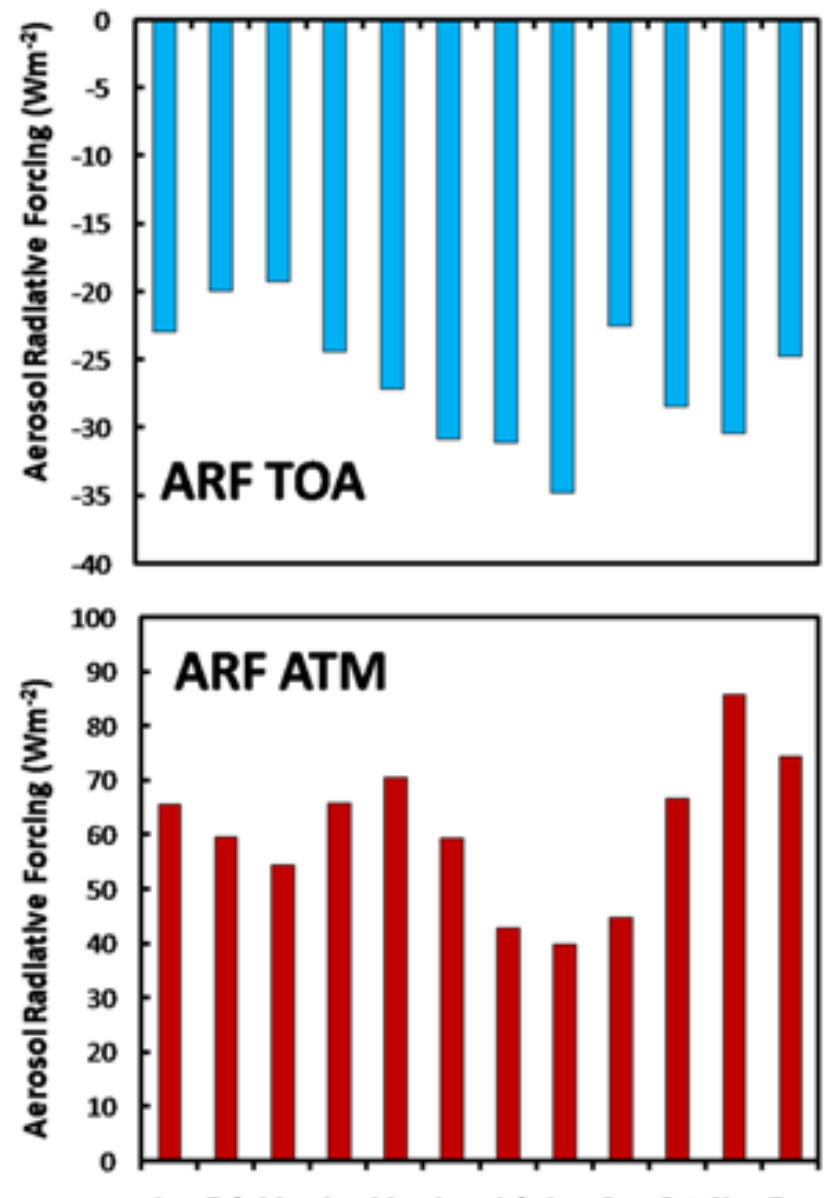

Jan Feb Mar Apr May Jun Jul Aug Sep Oct Now Dec

Fig 3. Monthly average (period: 2001-2015) ARFestimated over Kanpur at surface (SFC),atmosphere (ATM) and at the top ofatmosphere (TOA). 
The monthly mean ARF estimated during the period 2001-2015 over Kanpur is shown in Figure 3. During the months October to December, the surface ARF measurements are large in value. Contrary to this, the moderate values observed in the measurements of TOA forcing means that during this duration, the large attenuation in surface arriving solar radiation is mainly due to the presence of anthropogenic aerosols. The small values observed in the measurements of ARF at TOA imply the influence of absorbing aerosols present during the months of February and March. The large negative ARF values at TOA shows the influence of scattering aerosols that modifies the ARF from less negative value to more negative value, especially during the months from Jun to Aug. The simultaneous decrease in incoming solar rays leads to intensive solar heating as noted from the magnitudes of bars obtained for SFC and ATM forcing.

ISRO has conducted Aerosol Radiative Forcing programme over India (ARFI) for estimating radiative forcing in Vikram Sharabhai Space Centre Trivandrum. The researchers from different part of the country presented significant results during last two decades. The estimated values of ARF across the Bay of Bengal, at the SFC, ATM and TOA are found about -15 to -24 $\mathrm{Wm}^{-2},+13$ to $+20 \mathrm{Wm}^{-2}$ and -2 to $-4 \mathrm{Wm}^{-2}$ respectively ${ }^{(38)}$.INDOEX (Indian Ocean experiment) ${ }^{(39)}$ has conducted a study over the Indian Ocean to know the impacts of anthropogenic aerosols and found that anthropogenic aerosols attenuate the incoming solarray by an amount of $-50 \mathrm{Wm}^{-2}$. The ARF values obtained from the Visakhapatnam ARFI network station ${ }^{(40)}$, at the SFC, ATM and TOA are found to about $-16.33 \mathrm{Wm}^{-2},+20.19 \mathrm{Wm}^{-2}$ and $+3.86 \mathrm{Wm}^{-2}$ respectively. Pandithurai et al., 2004 ${ }^{(41)}$ recorded outcomes over Pune urban region and found a significant attenuation in incident solar radiation by an amount of 33 $\mathrm{Wm}^{-2}$ with approximately zero value of forcing at the TOA.Srivastava et al., 2012 reported results with location having high altitude such as at Nainital ${ }^{(42)}$ and found that the mean ARF at the ATM and SFC estimated to about $+14 \mathrm{Wm}^{-2}$ and $-14 \mathrm{Wm}^{-2}$ respectively having approximately zero forcing at the TOA. Dibrugarh is a rural area, the ARF values reported at the SFC, TOA and ATM are found with values $-29 \mathrm{Wm}^{-2},-0.9$ and $+28 \mathrm{Wm}^{-2}$ respectively ${ }^{(43)}$. Results also reported from national capital Delhi, the ARF at the SFC, TOA and ATM recorded to about $-77 \mathrm{Wm}^{-2},+3.3 \mathrm{Wm}^{-2}$ and $+80.3 \mathrm{Wm}^{-2}$ respectively. In another study, the mean ARF at the SFC, TOA and ATM are recorded with values $-67 \mathrm{Wm}^{-2}, 4 \mathrm{Wm}^{-2}$ and $+71 \mathrm{Wm}^{-2}$ respectively ${ }^{(44)}$. The seasonal ARF results over various Indian regions are presented in Table 1.

Table 1. Seasonal clear-sky ARF over India

\begin{tabular}{llllll}
\hline \multirow{2}{*}{ Locations } & \multicolumn{2}{l}{ Surface forcing $(\mathbf{W m}-\mathbf{2})$} & \multicolumn{2}{l}{ Atmospheric forcing $(\mathbf{W m}-\mathbf{2})$} & \multirow{2}{*}{ Reference } \\
\cline { 2 - 5 } & Pre-monsoon & Winter & Pre-monsoon & Winter & Present study \\
\hline Kanpur $\left(23.43^{\circ} \mathrm{N} / 80.33^{\circ} \mathrm{E}\right)$ & -87.67 & -87.98 & 63.99 & 65.76 & Sarkar et al., 2006 \\
Nagpur $\left(21.1^{\circ} \mathrm{N} / 79.3^{\circ} \mathrm{E}\right)$ & -38.1 & -37.3 & 5.3 & 24.3 & Sarkar et al., 2006 \\
Trivandrum $\left(8.55^{\circ} \mathrm{N} / 77.0^{\circ} \mathrm{E}\right)$ & -18.7 & -16.0 & 12.0 & 15.4 & Sarkar et al., 2006 \\
Varanasi $\left(25.3^{\circ} \mathrm{N} / 82.9^{\circ} \mathrm{E}\right)$ & -46.4 & -29.5 & 3.2 & 14.8 & Sarkar et al., 2006 \\
Kanpur $\left(23.43^{\circ} \mathrm{N} / 80.33^{\circ} \mathrm{E}\right)$ & -71.0 & -44.4 & 38.3 & 39.8 & Sarkar et al., 2006 \\
Kolkata $\left(22.5^{\circ} \mathrm{N} / 88.4^{\circ} \mathrm{E}\right)$ & -56.3 & -42.6 & 23.5 & 28.1 & Sreekanth et al., 2007 \\
Visakhapatnam $\left(17.7^{\circ} \mathrm{N} / 83.8^{\circ} \mathrm{E}\right)$ & -16.8 & -35.8 & 20.8 & 44.2 & Pathak et al., 2010 \\
Dibrugarh $\left(27.3^{\circ} \mathrm{N} / 94.6^{\circ} \mathrm{E}\right)$ & -37.1 & -34.2 & 35.7 & 33.2 & Ganguly \& Jayara- \\
Ahmadabad $\left(23.03^{\circ} \mathrm{N} / 72.55^{\circ} \mathrm{E}\right)$ & -41.4 & -54.0 & 48.0 & 28.0 & man, 2006 \\
& & & & &
\end{tabular}

\subsection{Aerosol radiative forcing efficiency}

It is the rate of forcing the atmosphere per unit AOD at wavelength at $500 \mathrm{~nm}$. In present study, the radiative forcing efficiency $\left(\Delta \mathrm{F}^{\mathrm{Eff}}\right)$ of aerosols at TOA and SFC has been analyzed by taking into account AERONET radiative transfer model. The forcing efficiency is much responsive to aerosol-solar interaction particularly for absorbing aerosols and greatly responded to the aerosol optical model. Therefore, radiative forcing efficiency is a good approach to distinguish the kinds of aerosols as it has greatly influenced by absorbing and scattering nature of particles. Moreover, it may also greatly have influenced by SSA and surface albedo. The low SSA means more absorbing types of aerosols where a large value of aerosol radiative efficiency forcing has been observed as shown in Figure 4 (a). On the other hand, aerosol shows a lower efficiency per unit of AOD increase at $500 \mathrm{~nm}$ at the TOA as shown in Figure 4(b). 


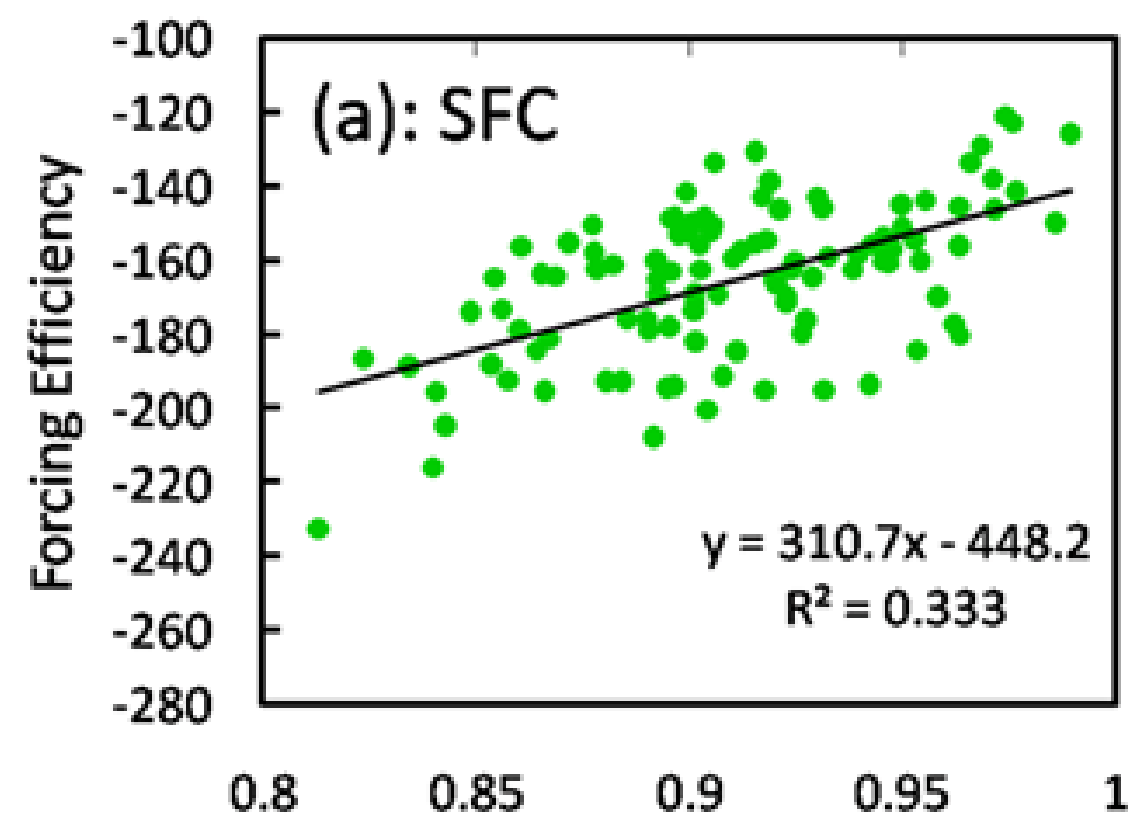

SSA at $1020 \mathrm{~nm}$

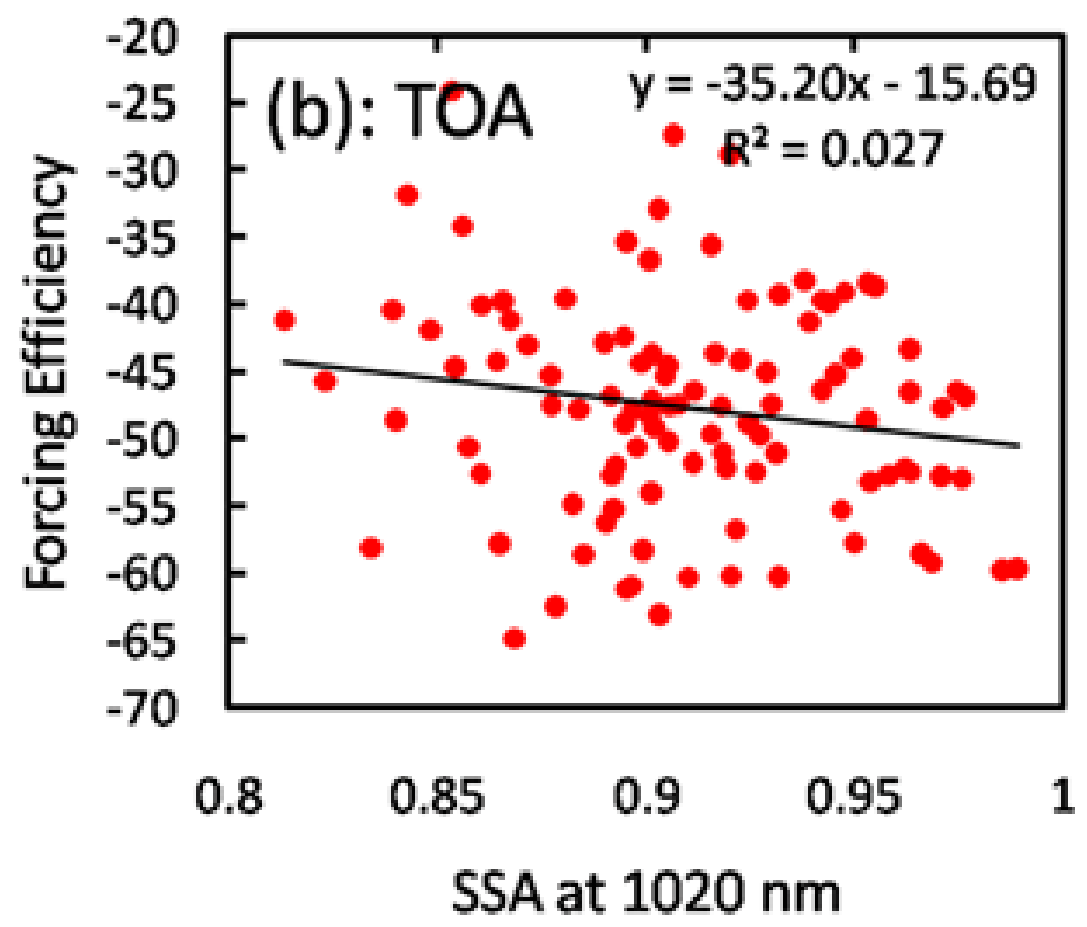

Fig 4. Aerosol radiative forcing efficiency $\left(\mathrm{Wm}^{-2} \mathrm{AOD}^{-1}\right)$ of daily average response to SSA at $1020 \mathrm{~nm}$

This indicates that absorption process of aerosol has reduced a significant fraction of energy as that energy is back scattered towards the space and thus responsible to maintain the large percentage of sun energy in the atmosphere. The average monthly values of aerosol radiative forcing efficiency of daily average are $-165 \pm 26 \mathrm{Wm}^{-2} \mathrm{AOD}^{-1}$ and $-47 \pm 10 \mathrm{Wm}^{-2} \mathrm{AOD}^{-1}$ at the SFC and TOA respectively. This indicates a significant effect of aerosol-solar absorption at surface thereby give rise to more cooling. There is a loss in solar rays arriving at the surface because of the scattering of radiation back towards the space which gives rise 
to cooling of climate system ${ }^{(45)}$. The small TOA forcing efficiency associated with the high surface forcing indicates a strong absorption due to high aerosol loading as shown in Figure 5 . It is found that there is an increase in backscattered energy towards TOA when SSA increases. The aerosols of absorbing nature are found very powerful at the SFC in comparison to at the TOA, where they scatter little energy back into the atmosphere. These characteristics are examined after Figure 4.

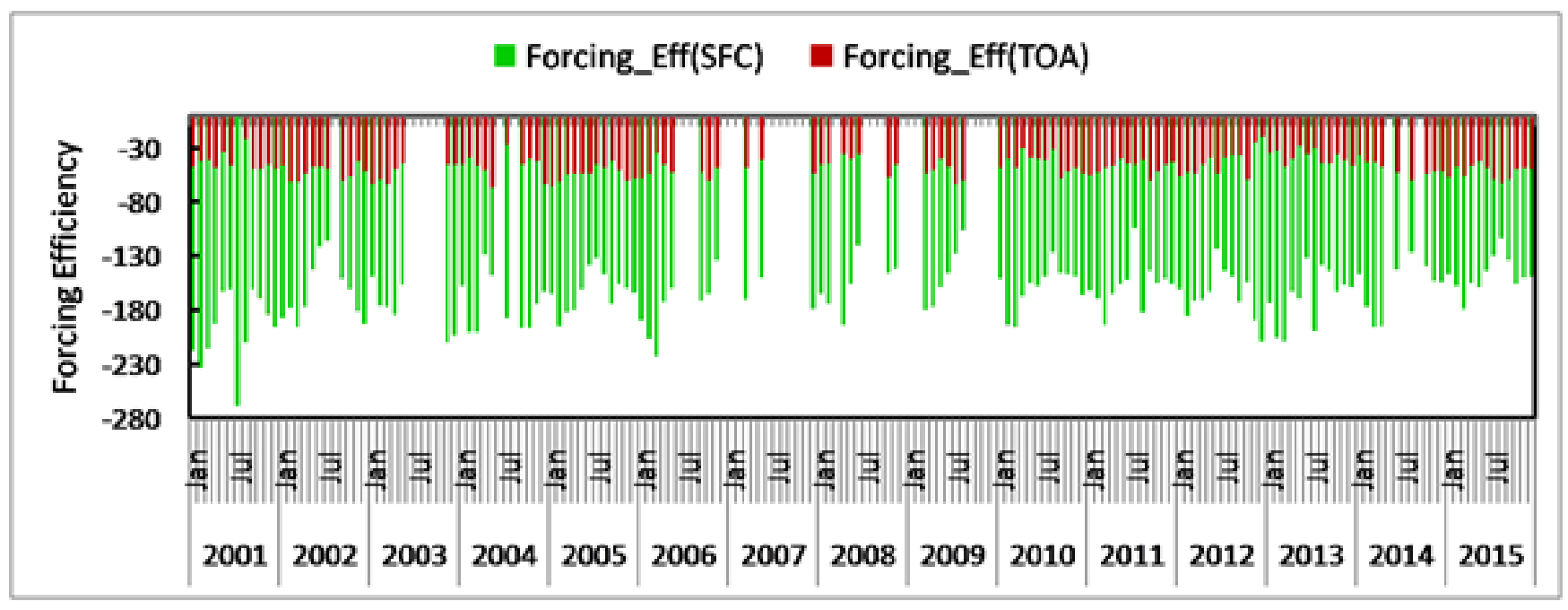

Fig 5. Monthly variation in aerosol radiative forcing efficiency $\left(\mathrm{Wm}^{-2} \mathrm{AOD}^{-1}\right)$ of daily average at surface (SFC) and top of the atmosphere (TOA)

\section{Conclusions}

AERONET radiative transfer approach is used to find aerosol radiative forcing. This study investigated the seasonal and spectral variations of ARF along with aerosol radiative frequency with special reference to Kanpur region (IGP) by using AERONET data for the period 2001 -2015. The main concluding points of this study are:

1. The seasonal variation of ARF implies that the values of top of atmosphere ARF have been found more negative during monsoon and post-monsoon seasons while less negative during pre-monsoon and winter seasons. The seasonal largest atmospheric ARF estimated during post-monsoon while the smallest during monsoon. During monsoon to postmonsoon period, a quick variation in seasonal shift in ARF has been observed. The value of surface ARF in post-monsoon period occurred approximately 1.3 times greater than monsoon period.

2. Spectral variation in monthly average ARF implies that large values of surface ARF and moderate values of top of atmosphere ARF have been found during the months of October to December. Small values of top of atmosphere ARF have been observed during the months February and March which indicates a large fraction of absorbing types of aerosols present in the atmosphere. Large negative values of top of atmosphere ARF have been found during the months of June to August which indicates a significant fraction of scattering types of aerosols present in the atmosphere.

3. It is concluded that the values of ARF over IGP, northwestern and northeastern parts of India during pre-monsoon period are higher in comparison to other seasons because here the particles of large size are dominant with significant proportion of desert dust. In winter, the ARF values are found higher over the coastal regions of eastern and southern parts of India because of the predominance of large amount of anthropogenic aerosols. In post-monsoon period, the ARF values are higher over western India because of the dominance nature of continental aerosols present there along with a considerable proportion of anthropogenic aerosols. This implies that in eastern and northern parts of India, there is attenuation in surface arriving solar rays due to desert dust in significant amount. On the other hand, in southern and western parts of India, the more attenuation in surface arriving sun ray is because of anthropogenic aerosols present in considerable amount. 


\section{Acknowledgments}

The authors sincerely extend warm gratitude to Dean Career Point University Kota (Research and Higher Studies) for their amiable help. We also appreciate various applications, data resources and programmes like AERONET and ARFI which have been utilized and ascribed in the present work.

\section{References}

1) Charlson RJ, Langner J, Rodhe H, Leovy CB, Warren SG. Perturbation of the northern-hemisphere radiative balance by backscattering from anthropogenic sulphate aerosols. Tellus Series. 1991;43(4):152-163. Available from: https://doi.org/10.3402/tellusa.v43i4.11944.

2) CHARLSON RJ, SCHWARTZ SE, HALES JM, CESS RD, COAKLEY JA, HANSEN JE, et al. Climate Forcing by Anthropogenic Aerosols. Science. 1992;255(5043):423-430. Available from: https://dx.doi.org/10.1126/science.255.5043.423.

3) Andrews E, Sheridan PJ, Fiebig M, McComiskey A, Ogren JA, Arnott P, et al. Comparison of methods for deriving aerosol asymmetry parameter. Journal of Geophysical Research. 2006;111(D5). Available from: https://dx.doi.org/10.1029/2004jd005734.

4) Ramanathan V, Crutzen PJ, Kiehl JT, Rosenfeld D. Aerosols, climate and the hydrological cycle. Science. 2001;294(5549):2119-2124. Available from: https://doi.org/10.1126/science.1064034.

5) Satheesh SK, Ramanathan V. Large differences in tropical aerosol forcing at the top of the atmosphere and Earth's surface. Nature. 2000;405(6782):60-63. Available from: https://dx.doi.org/10.1038/35011039.

6) Hansen J, Nazarenko L. Soot climate forcing via snow and ice albedos. Proceedings of the National Academy of Sciences. 2004;101(2):423-428. Available from: https://dx.doi.org/10.1073/pnas.2237157100.

7) Ohara T, Akimoto H, Kurokawa J, Horii N, Yamaji K, Yan X, et al. An Asian emission inventory of anthropogenic emission sources for the period 1980\&ndash;2020. Atmospheric Chemistry and Physics. 2007;7:4419-4444. Available from: https://dx.doi.org/10.5194/acp-7-4419-2007.

8) Xu B, Cao J, Hansen J. Black soot and the survival of Tibetan glaciers. In: and others, editor. Proceedings of National Academy of Sciences (USA);vol. 106 of 52. 2009;p. 22114-22118. Available from: https://doi.org/10.1073/pnas.0910444106.

9) Lau KM, Kim KM, Kim MK. Asian monsoon anomalies induced by aerosol direct forcing: the role of the Tibetan Plateau. Climate Dynamics. 2006;26(7):855-864. Available from: https://doi.org/10.1007/s00382-006-0114-z.

10) Lau KM, Kim KM. Observational relationships between aerosol and Asian monsoon rainfall, and circulation. Geophysical Research Letters. 2006;33(21). Available from: https://dx.doi.org/10.1029/2006gl027546.

11) Kulkarni K, Bahuguna IM, Rathore BP. Glacial retreat in Himalaya using Indian remote sensing satellite data. Current Science. 2007;92(1):69-83. Available from: https://wwwresearchgate.net/publication/260673054.

12) Lau KM, Kim MK, Lee WS. Enhanced surface warming and accelerated snowmelt in the Himalayas and Tibetan Plateau induced by absorbing aerosols. Environmental Research Letters. 2010;5(2). Available from: https://doi.org/10.1088/1748-9326/5/2/025204.

13) Guleria RP, Kuniyal JC, Rawat PS. Aerosols optical properties in dynamic atmosphere in the north-western part of the Indian Himalaya: a comparative study from ground and satellite based observations. Atmospheric Research. 2011;101(3):726-738. Available from: https://doi.org/10.1016/jatmosres.2011. 04.018 .

14) Gautam R, Hsu NC, Lau KM, Kafatos M. Aerosol and rainfall variability over the Indian monsoon region: distributions, trends and coupling. Annales Geophysicae. 2009;27(9):3691-3703. Available from: https://dx.doi.org/10.5194/angeo-27-3691-2009.

15) Gautam R, Hsu NC, Lau KM. Pre monsoon aerosol characterization and radiative effects over the Indo-Gangetic Plains; implications for regional climate warming. Journal of Geophysical Research. 2010;115. Available from: https://doi.org/10.1029/2010JD013819.

16) Kulkarni AV, Kumar GV, Negi HS, Srinivasan J, Satheesh SK. The effect of black carbon on reflectance of snow in the accumulation area of glaciers in the Baspa basin, Himachal Pradesh, India. The Cryosphere Discussions. 2013;7(2):1359-1382. Available from: https://dx.doi.org/10.5194/tcd-7-1359-2013.

17) Sarangi C, Tripathi SN, Mishra AK, Goel A, Welton EJ. Elevated aerosol layers and their radiative impact over Kanpur during monsoon onset period. Journal of Geophysical Research: Atmospheres. 2016;121(13):7936-7957. Available from: https://dx.doi.org/10.1002/2015jd024711.

18) Shrestha S, Peel M, Moore G. Development of a Regression Model for Estimating Daily Radiative Forcing Due to Atmospheric Aerosols from Moderate Resolution Imaging Spectrometers (MODIS) Data in the Indo Gangetic Plain (IGP). Atmosphere. 2018;9:405-405. Available from: https://dx.doi.org/10. 3390/atmos9100405.

19) Moorthy KK, Niranjan K, Narasimhamurthy B, Agashe VV, Murthy BVK. Aerosol climatology over India, ISRO-GBP MWR network and data base. In: Scientific Report (India), SR-03-99. Indian Space Research Organization(ISRO). 1999. Available from: https://books.google.co.in/books/about/ AerosolClimatologyOverIndia.html?id=KrEEOgAACAAJ\&rediresc $=y$.

20) Forster P, Ramaswamy V, Artaxo P. Changes in atmospheric constituents and in radiative forcing, Climate Change 2007: The Physical Science Basis. Contribution of Working Group Ito the Fourth Assessment Report of the Intergovernmental Panel on Climate ChangeCambridge. Cambridge. University Press. 2007. Available from: http://www.cambridge.org/catalogue/catalogue.asp?isbn=9780521705967.

21) Srivastava AK, Tiwari S, Devara PCS, Bisht DS, Srivastava MK, Tripathi SN, et al. Pre-monsoon aerosol characteristics over the Indo-Gangetic Basin: implications to climatic impact. Annales Geophysicae. 2011;29(5):789-804. Available from: https://dx.doi.org/10.5194/angeo-29-789-2011.

22) Zhou M, Zhang L, Chen D, Gu Y, Fu TM, Gao M, et al. The impact of aerosol-radiation interactions on the effectiveness of emission control measures. Environmental Research Letters. 2019;14(2). Available from: https://doi.org/10.1088/1748-9326/aaf27d.

23) Ezhova E, Ylivinkka I, Kuusk J, Komsaare K, Vana M, Krasnova A, et al. Direct effect of aerosols on solar radiation and gross primary production in boreal and hemiboreal forests. Atmospheric Chemistry and Physics. 2018;18(24):17863-17881. Available from: https://dx.doi.org/10.5194/acp-18-17863-2018.

24) Liu S, Xing J, Zhao B, Wang J, Wang S, Zhang X, et al. Understanding of Aerosol-Climate Interactions in China: Aerosol Impacts on Solar Radiation, Temperature, Cloud, and Precipitation and Its Changes Under Future Climate and Emission Scenarios. Current Pollution Reports. 2019;5(2):36-51. Available from: https://dx.doi.org/10.1007/s40726-019-00107-6.

25) Myhre G, Myhre CL, Samset BH, Storelvmo T. Aerosols and their Relation to Global Climate and Climate Sensitivity. Nature Education Knowledge. 2013;4(5). Available from: https://www.nature.com/scitable/knowledge/library/aerosols-and-their-relation-to-global-climate-102215345/\#.

26) Sarangi C, Tripathi SN, Mishra AK, Goel A, Welton EJ. Elevated aerosol layers and their radiative impact over Kanpur during monsoon onset period. Journal of Geophysical Research: Atmospheres. 2016;121(13):7936-7957. Available from: https://dx.doi.org/10.1002/2015jd024711. 
27) Ricchiazzi P, Yang S, Gautier C, Sowle D. SBDART: A Research and Teaching Software Tool for Plane-Parallel Radiative Transfer in the Earth's Atmosphere. Bulletin of the American Meteorological Society. 1998;79(10):2101-2114. Available from: https://dx.doi.org/10.1175/1520-0477(1998)079<2101:sarats>2. $0 . \operatorname{co} ; 2$.

28) Fu Q, Liou KN. On the Correlatedk-Distribution Method for Radiative Transfer in Nonhomogeneous Atmospheres. Journal of the Atmospheric Sciences. 1992;49(22):2139-2156. Available from: https://dx.doi.org/10.1175/1520-0469(1992)049<2139:otcdmf $>2.0 . c 0 ; 2$.

29) Fu Q, Liou KN. Parameterization of the Radiative Properties of Cirrus Clouds. Journal of the Atmospheric Sciences. 1993;50(13):2008-2025. Available from: https://dx.doi.org/10.1175/1520-0469(1993)050<2008:potrpo >2.0.co;2.

30) Charlock TP, Rose FG, Rutan D, Jin Z, Fillmore D, Collins W. Global retrieval of the surface and atmospheric radiation budget and direct aerosol forcing. In: Conference on Satellite Meteorology. Norfolk, U.K,. AMS. 2004. Available from: https://doi.org/10.1029/2005JD006312,2006.

31) Dubuisson P. Water vapor retrieval over ocean using near-infrared radiometry. Journal of Geophysical Research. 2004;109(D19). Available from: https://dx.doi.org/10.1029/2004jd004516.

32) Jin Z, Charlock TP, Rutledge K, Stamnes K, Wang Y. Analytical solution of radiative transfer in the coupled atmosphere-ocean system with a rough surface. Applied Optics. 2006;45(28):7443-7443. Available from: https://dx.doi.org/10.1364/ao.45.007443.

33) Jin Z, Stamnes K. Radiative transfer in nonuniformly refracting layered media: atmosphere-ocean system. Applied Optics. 1994;33(3):431-431. Available from: https://dx.doi.org/10.1364/ao.33.000431.

34) Hienola AI, O’Donnell D, Pietikäinen JP, Svensson J, Lihavainen H, Virkkula A, et al. The radiative impact of Nordic anthropogenic black carbon. Tellus B: Chemical and Physical Meteorology. 2016;68(1):27428-27428. Available from: https://dx.doi.org/10.3402/tellusb.v68.27428.

35) Satheesh SK, Ramanathan V, Holben BN, Moorthy KK, Loeb NG, Maring H, et al. Chemical, microphysical, and radiative effects of Indian Ocean aerosols. Journal of Geophysical Research: Atmospheres. 2002;107(D23). Available from: https://dx.doi.org/10.1029/2002jd002463.

36) Liou KN. An Introduction to Atmospheric Radiation. New York. Elsevier. 2002. Available from: http://lib.iszfirk.ru/An\%20Introduction\%20to\% 20Atmospheric\%20Radiation.\%202nd\%20ed.\%20(Liou\%20K.).pdf.

37) Kumar R, Kumar G, Kumar M, Guleria RP. Spectral and Seasonal variations of aerosol optical depth with special reference to Kanpur, Indo-Gangetic Basin. Indian Journal of Science and Technology. 2020;13(21):2119-2137. Available from: https://doi.org/10.17485/IJST/v13i21.364.

38) Vinoj V, Babu SS, Satheesh SK, Moorthy KK, Kaufman YJ. Radiative forcing by aerosols over the Bay of Bengal region derived from ship-borne, island-based and satellite (moderate-resolution imaging spectro-radiometer) observations. Journal of Geophysical Research. 2004. Available from: https://doi.org/10.1029/2003JD004329.

39) Satheesh SK, Ramanathan V, Jones XL, Lobert JM, Podgorny IA, Prospero JM, et al. A model for natural and anthropogenic aerosols over the tropical Indian Ocean derived from INDOEX data. Journal of Geophysical Research. 1999;104. Available from: https://doi.org/10.1029/1999JD900478.

40) Sreekanth V, Niranjan K, Madhavan BL. Radiative forcing of black carbon over eastern India. Geophysical Research Letters. 2007;34(17). Available from: https://dx.doi.org/10.1029/2007gl030377.

41) Pandithurai G, Pinker RT, Takamura T, Devara PCS. Aerosol radiative forcing over a tropical urban site in India. Geophysical Research Letters. 2004;31(12):n/a-n/a. Available from: https://dx.doi.org/10.1029/2004gl019702.

42) Srivastava AK, Ram K, Pant P, Hegde P, Joshi H. Black carbon aerosols over Manora Peak in the Indian Himalayan foothills: implications for climate forcing. Environmental Research Letters. 2012;7(1):014002-014002. Available from: https://dx.doi.org/10.1088/1748-9326/7/1/014002.

43) Pathak B, Kalita G, Bhuyan K, Bhuyan PK, Moorthy KK. Aerosol temporal characteristics and its impact on shortwave radiative forcing at a location in the northeast of India. Journal of Geophysical Research. 2010;115(D19). Available from: https://dx.doi.org/10.1029/2009jd013462.

44) Singh S, Soni K, Bano T, Tanwar RS, Nath S, Arya BC. Clear-sky direct aerosol radiative forcing variations over mega-city Delhi. Annales Geophysicae. 2010;28(5):1157-1166. Available from: https://dx.doi.org/10.5194/angeo-28-1157-2010.

45) Kumar R, Kumar G, Kumar A. Radiative properties of aerosols. AIP Conference Proceeding. 2018. Available from: https://doi.org/10.1063/1.5083605. 